\title{
Musicalizando os participantes do 310 SEURS
}

Área Temática Educação

\author{
Isabel Bonat Hirsch ${ }^{1}$ \\ Dionísio de Lemos Souza ${ }^{2}$ \\ Lia Viegas Mariz de Oliveira Pelizzon² \\ Priscila Kuhn Scherdien ${ }^{2}$ \\ Rodrigo Madrid Peres Vieira ${ }^{2}$ \\ Vitor Hugo Rodrigues Manzke²
}

\section{RESUMO}

0 presente minicurso é fruto de um projeto de extensão oferecido pelos acadêmicos do Curso de Música, modalidade Licenciatura, do Centro de Artes da Universidade Federal de Pelotas, intitulado Oficina de Repertório Musical para Professores. 0 minicurso foi elaborado para proporcionar atividades de musicalização, desenvolvendo a percepção musical dos participantes do $31^{\circ}$ o SEURS, e, mais especificamente, propor atividades que desenvolvam habilidades de coordenação motora e de atenção, vivenciando padrões musicais a partir de sons produzidos com o corpo.

PALAVRAS-CHAVE: Educação Musical. Formação Continuada. Percussão Corporal. Oficina de Musicalização.

\footnotetext{
${ }^{1}$ Professora coordenadora, mestre, Centro de Artes, Universidade Federal de Pelotas. E-mail: isabel.hirsch@gmail.com.

${ }^{2}$ Acadêmicos do Curso de Música - modalidade Licenciatura, Centro de Artes, Universidade Federal de Pelotas.
} 


\section{Introdução}

Muitos pesquisadores na área de educação musical vêm apontando sobre a tentativa de inserção da música nas escolas da educação básica desde que a Lei 11.769/08 foi promulgada (ARTE NA ESCOLA, 2010). No entanto, sabe-se que ainda é difícil fazer com que todos os estudantes tenham acesso ao ensino de música nos currículos escolares, sejam eles de escola pública ou de escola particular. 0 minicurso "Musicalizando os participantes do 31을 SEURS", neste sentido, vêm proporcionar momentos de musicalização, desenvolvendo a percepção musical, e, mais especificamente, propor atividades que desenvolvam habilidades de coordenação motora e de atenção, vivenciando padrões musicais a partir de sons produzidos com o corpo. Este trabalho faz com que se perceba a necessidade que se tem de desenvolver a percepção musical nas pessoas, já que muitos jovens e adultos não tiveram a oportunidade em sala de aula, e mostrar que é tão importante para o ser humano, pois a música também colabora na atenção, concentração, coordenação e tantas outras habilidades.

\section{Metodologia}

De acordo com as regras do evento, o minicurso tem duas horas de duração. 0 número de participantes é de, no mínimo, 25 e, no máximo, de 40 pessoas. 0 espaço físico necessário é de uma sala ampla, sem cadeiras, com capacidade para 40 pessoas. Os materiais utilizados são 40 colchonetes e um aparelho de som com entrada para pen-drive. Aponta-se a necessidade dos participantes estarem vestidos com roupas confortáveis.

\section{Considerações Finais}

Esperamos que o minicurso "Musicalizando os participantes do 31ํㅗㄴ traga subsídios importantes e fáceis de serem assimilados pelos participantes. 
Dessa maneira, poderemos atingir nossos objetivos com o mínimo de qualidade desejável e com consciência das habilidades que estão sendo desenvolvidas nas atividades propostas.

\section{Referências}

ARTE NA ESCOLA. Música já é lei. Mas e agora? São Paulo, jan.-mar. 2010.

Disponível em: <http://pt.scribd.com/doc/29664983/Arte-e-Ensino-BoletimdoInstituto-Arte-na-Escola-n\%C2\%BA57>. Acesso em: 15 maio 2013. 